\title{
LINKAGE STUDY OF VOLTAGE-GATED POTASSIUM CHANNELS IN FAMILIAL MESIAL TEMPORAL LOBE EPILEPSY
}

\author{
Cláudia Vianna Maurer-Morelli', Rafael Breglio Marchesini', Rodrigo Secolin', \\ Neide Ferreira Santos', Eliane Kobayashi², Fernando Cendes², Iscia Lopes-Cendes'
}

\begin{abstract}
Voltage-gated potassium channels (VGKCs) play a critical role in the regulation of neuronal excitability and have been implicated in some types of epilepsies. Recently, autoimmune limbic encephalitis (LE) was associated with antibodies against VGKC. In addition, patients with LE showed partial epilepsy and increased T2 signal abnormalities in limbic structures. We have reported familial mesial temporal lobe epilepsy (FMTLE) associated with hippocampal atrophy (HA) and other signs of mesial temporal sclerosis detected by magnetic resonance imaging (MRI). In order to investigate whether VGKC may be associated to HA present in FMTLE, we perform linkage study in these candidate genes. Seventy-three microsatellites markers were genotyped in different human autosomal chromosome. Two-point LOD scores did not show evidence for linkage with any of the microsatellite markers genotyped (Zmax ranging from 0.11 to9.53 at $\theta=0.00$ ). In the present study, linkage data showed no evidence that VGKC are involved in the determination of HA in FMTLE.
\end{abstract}

KEY WORDS: hippocampal sclerosis, genetics, microsatellites.

\begin{abstract}
Análise de ligação dos canais de potássio voltagem-dependente na epilepsia de lobo temporal mesial familiar

RESUMO - Canais de potássio voltagem-dependentes (CPVD) desempenham importante papel na excitabilidade neuronal e estão associados a determinados tipos de epilepsia. Recentemente, um tipo de encefalite límbica autoimune (EL) foi associado com anticorpos contra CPVD. Além disso, há relatos de pacientes com EL e epilepsia parcial, além de hipersinal em regiões límbicas detectadas em imagens de ressonância magnética (IRM). Nós temos descrito a epilepsia de lobo temporal mesial familial (ELTMF) associada à atrofia hipocampal (AH) e outros sinais de esclerose mesial temporal observadas em IRM. Para investigar se os CPVD podem estar associados com a AH identificada na ELTMF, empregamos o estudo de ligação genética nesses genes candidatos. Setenta e três marcadores microssatélites foram genotipados e o LOD score de dois pontos mostrou Zmax variando de 0.11 a -9.53 para $\theta=0.00$. No presente estudo, os dados obtidos com a análise de ligação mostram que os CPVD não estão envolvidos na determinação da AH na ELTMF.
\end{abstract}

PALAVRAS-CHAVE: esclerose hipocampal, genética, marcadores microssatélites.

Epilepsy is a common neurological disorder that affects $1.5-2 \%$ of world population'. This condition is characterized by abnormal neuronal hyperexcitability and episodes of synchronized firing by large group of neurons, which clinically manifests as a seizure. It is well known that voltage-gated potassium channels (VGKC) play an important role in the regulation of neuronal excitability by modulate resting membrane potential and control of the shape and frequency of action potentials. Therefore, mutations in
VGKC genes are found in many neurological disorders, including epilepsies. In fact, VGKC have been implicated in some types of idiophatic and symptomatic epilepsies ${ }^{2-4}$.

Recently, patients presenting a type of autoimmune limbic encephalitis (LE) showed strong relationship with VGKC-antibodies ${ }^{5}$. LE is associated with memory loss, partial seizures and increased $\mathrm{T} 2$ signal abnormalities in limbic structures in magnetic resonance imaging (MRI) ${ }^{5-8}$. In addition, an immunostain-

'Department of Medical Genetics, Universidade Estadual de Campinas (UNICAMP), Campinas SP, Brazil; ${ }^{2}$ Department of Neurology, UNICAMP. This study was supported by FAPESP (Fundação de Amparo à Pesquisa do Estado de São Paulo, Brazil), grants 02/104350 and 03/13424-1.

Received 6 July 2006. Accepted 28 October 2006.

Dra. Iscia Lopes-Cendes - Department of Medical Genetics, FCM I UNICAMP - Rua Tessalia Vieira de Camargo 126 - $13084-971$ Campinas SP - Brasil.E-mail: icendes@unicamp.br 
Arg Neuropsiquiatr 2007;65(1)

21

ing study showed that hippocampus is a preferential location of VGKC-antibodies in LE$^{9}$. Hippocampal atrophy (HA) and increased T2 signal in limbic structyres are a frequent MRI finding related with mesial temporal sclerosis (MTS) identified in patients with mesial temporal lobe epilepsy (MTLE) ${ }^{10-11}$. MTLE is the most common partial epilepsy in adults and it is firequently associated with an early-life initial insult, such as a childhood prolonged febrile seizure ${ }^{12-14}$.

We were the first to identify a type of MTLE with clear evident of familial recurrence (FMTLE) ${ }^{15-17}$. Although, most of the affected individuals in FMTLE have a benign course of the disease ${ }^{15} \mathrm{MRI}$ studies showed signs of clear-cut HA in most affected ind- viduals, including patients who had only a single partial seizure as well as in asymptomatic, at risk, first degree relatives ${ }^{15-18}$. This evidence supports the idea that a significant genetic predisposition for the devilopment of HA is present in FMTLE. Based on these findings, together with the important association between seizure, VGKC and hippocampal abnormalities, we carried out linkage studies in FMTLE in order to investigate whether VGKC gene may be determining the HA present in these families.

METHOD

Families - Diagnosis of patients with FMTLE was stablisped in accordance with the ILAE criteria ${ }^{19}$. The study co-
Chromosome 1

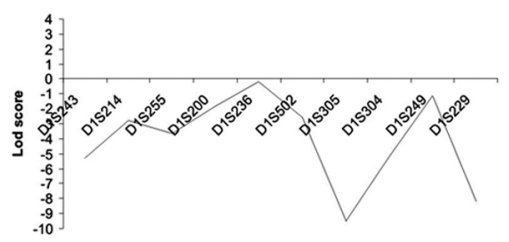

Chromosome 6

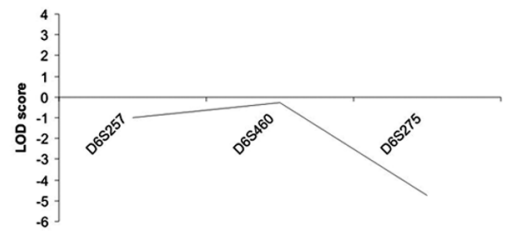

Chromosome 11

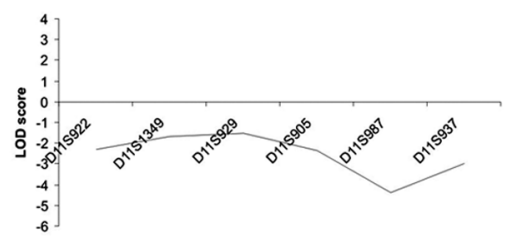

Chromosome 16

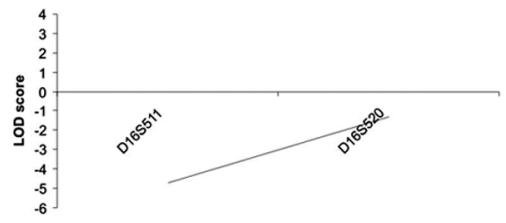

Chromosome 19

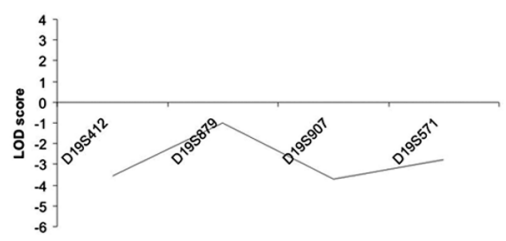

Chromosome 2

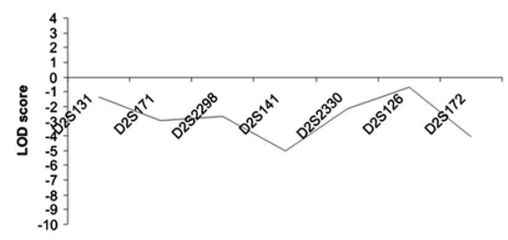

Chromosome 7

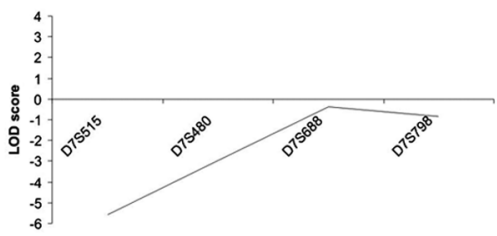

Chromosome 12

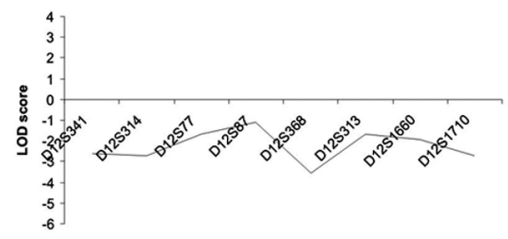

Chromosome 17

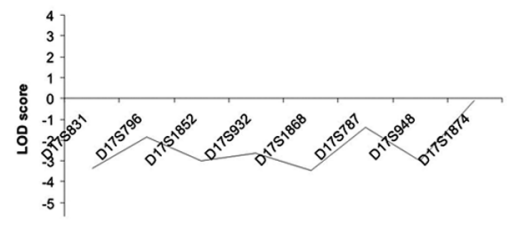

Chromosome 20

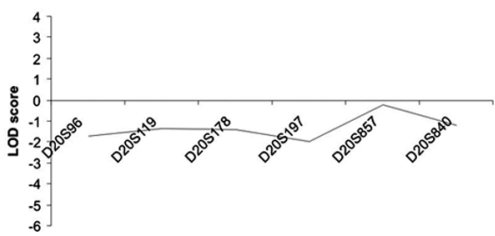

Chromosome 3

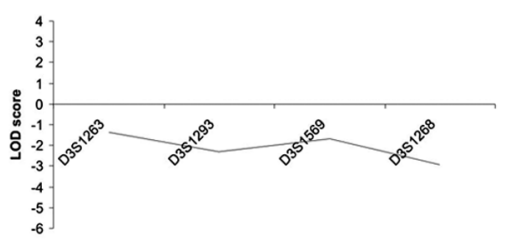

Chromosome 8

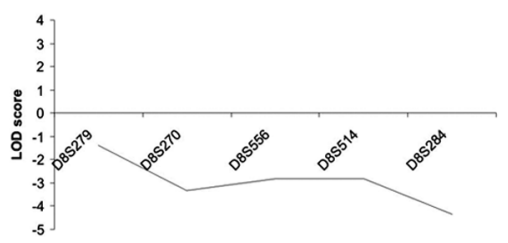

Chromosome 14

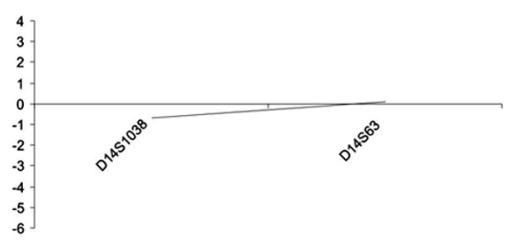

Chromosome 18

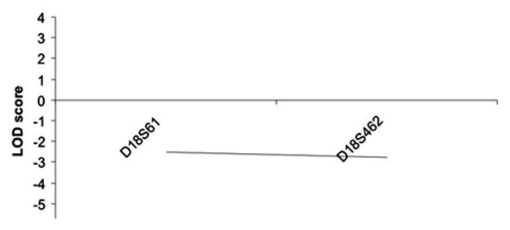

Chromosome 21

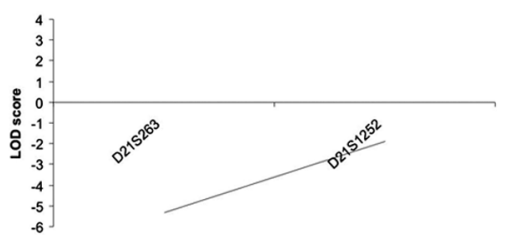

Figure. Voltage-gated potassium channels genes studied by linkage analysis. LOD scores ranged from 0.11 to -9.53 for the 73 microsatellites markers genotyped. 
hort is composed of 30 unrelated families segregating MTLE identified in our hospital service. Among these, we have selected two informative kindred for linkage analysis, named F-10 and F-26. A total of 57 individuals, including 29 patients were genotyped. Family ascertainment and detailed clinical description have been published ${ }^{15}$. All family members signed an informed consent for this research, which was approved by the Ethics Committee of our institution.

Genetic analysis - DNA was isolated from lymphocytes of fresh blood by standard methods. A set of 73 polymorphic dinucleotide repeat markers was choosen from the Marshfield Human Genetic Map, flanking 45 VGKC genes identified on different autosomal chromosomes. The sequences and genomic order of these markers are available in the MapViewer database on line (http://www.ncbi.nlm. nih.gov/mapview). Genotyping of microsatellite markers was accomplished by means of polymerase chain reaction (PCR) using a total volume of $12.5 \mu$ containing $50 \mathrm{ng}$ of genomic DNA; $100 \mathrm{ng}$ of each primer; $200 \mu \mathrm{M}$ of dGTP, dCTP and dTTP; $25 \mu \mathrm{M}$ of dATP; $1,5 \mu \mathrm{Ci}\left[{ }^{33} \mathrm{P}\right] \mathrm{dATP} ; 0,5$ units of Taq DNA polimerase and $1.5 \mathrm{mM}$ of $\mathrm{MgCl}$. The cycling parameters were as follows: initial denaturation at $94^{\circ} \mathrm{C}$ for three minutes; 35 cycles of denaturation at $94^{\circ} \mathrm{C}$ for 45 seconds; anneling at $57^{\circ} \mathrm{C}$ for 45 seconds; elongation at $72^{\circ} \mathrm{C}$ for 30 seconds and final extension at $72^{\circ} \mathrm{C}$ for one minute. PCR products were submitted to electrophoresis on $6 \%$ denaturing polyacrylamide gels, which were dried and exposed to X-ray films.

Linkage analysis - Linkage analysis was performed under the assumption of a dominant mode of inheritance with incomplete penetrance. Evidence for a dominant pattern of inheritance with Mendelian transmission was obtained from complex segregation analysis ${ }^{20}$. Two-point LOD scores were calculated by the MLINK program, version 5.1, of the LINKAGE computer package for each family separately. The region is considered positive for linkage when $Z$ max $\geq 3$.

\section{RESULTS}

Two-point maximum likelihood data for the 73 markers genotyped are summarized in Figure. No significant positive LOD scores were obtained for any of the markers genotyped. LOD scores ranged from 0.11 to -9.53 at $\theta=0.00$.

\section{DISCUSSION}

We have described a type of FMTLE in which most patients present HA not necessarily associated to the occurrence of seizures, suggesting that hippocampal abnormalities may be determined by genetic factors $^{15-18}$. Although FMTLE is a well-defined clinically syndrome the gene responsible for this condition has not been identified yet.

VGKC genes are good candidates for epilepsies ${ }^{21}$.
It is know that mutations in potassium channel genes are closely associated with disturbance in neuronal firing in humans and animals ${ }^{22,23}$. Many recent biochemical, immunological, neuroanatomical and molecular studies have contributed to elucidate the mechanisms by which ion channel subunits are involved in the normal functioning and disease in the mammalian central nervous system ${ }^{24-26}$.

The important description of HA and hyperintense T2 signal on MRI of patients with a type of autoimmune LE related with VGKC antibodies ${ }^{5,27}$ lead us to hypothesis the possible role of VGKC in FMTLE, since these imaging findings (HA and hyperintense T2 signal) are similar in both LE and FMTLE.

Linkage analysis is a powerful screening method to localize major genes responsible for inherited disorders and have contributed to the identification of many genes related with human disorders ${ }^{28,29}$. By this method we can confirm or exclude genetic linkage between selected markers and disease loci. Linkage analysis is also useful to investigate well localized candidate genes, which can circumvent extensive and time-consuming wide linkage studies. However, linkage analysis has had limited success when applied to mapping genes of minor effects or when the number of families is not sufficient to establish linkage. In addition, power to detect linkage is limited when the mode of inheritance is incorrectly specified.

Our study was undertaken in two large and informative families segregating MTLE, in an autosomal dominant mode of transmission ${ }^{20}$, insuring the success in obtaining significant and reproducible results. In the present study, we did not find any indication of linkage between VGKC and FMTLE, suggesting that potassium channel are not the major gene responsible for the phenotype founded in FMTLE.

Acknowledgements - We are grateful to all of the patients and their family members who participated in this study.

\section{REFERENCES}

1. Hauser WA, Annegers JF, Kurland LT. Incidence of epilepsy and unprovoked seizures in Rochester, Minnesota: 1935-1984. Epilepsia 1993; 34:453-468.

2. Biervert C, Steinlein OK. Structural and mutational analysis of KCNQ2, the major gene locus for benign familial neonatal convulsions. Hum Genet 1999;104:234-240.

3. Lerche H, Jurkat-Rott K, Lehmann-Horn F. Ion channels and epilepsy. Am J Med Genet 2001;106:146-159.

4. Roll P, Szepetowski P. Epilepsy and ionic channels. Epileptic Disord 2002;4:165-172.

5. Vincent A, Buckley C, Schott JM, et al. Potassium channel antibodyassociated encephalopathy: a potentially immunotherapy-responsive form of limbic encephalitis. Brain 2004;127:701-712. 6.

Bien CG, Schulze-Bonhage A, Deckert M, et al. Limbic encephalitis not associated with neoplasm as a cause of temporal lobe epilepsy. Neurology 2000;55:1823-1828. 
7. Pozo-Rosich P, Clover L, Saiz A, Vincent A, Graus F. Voltage-gated potassium channel antibodies in limbic encephalitis. Ann Neurol 2003; 54:530-533.

8. Thieben MJ, Lennon VA, Boeve BF, Aksamit AJ, Keegan M, Vernino S Potentially reversible autoimmune limbic encephalitis with neuronal potassium channel antibody. Neurology 2004;62:1177-1182.

9. Buckley C, Oger J, Clover L, et al. Potassium channel antibodies in two patients with reversible limbic encephalitis. Ann Neurol 2001;50:73-78.

10. Berkovic SF, Andermann F, Olivier A, et al. Hippocampal sclerosis in temporal lobe epilepsy demonstrated by magnetic resonance imaging. Ann Neurol 1991;29:175-182.

11. Coan AC, Kobayashi E, Lopes-Cendes I, Li LM, Cendes F. Quantification of hippocampal signal intensity in patients with mesial temporal lobe epilepsy. J Neuroimaging 2003;13:228-233.

12. Abou-Khalil B, Andermann E, Andermann F, Olivier A, Quesney LF, Temporal lobe epilepsy after prolonged febrile convulsions: excellent outcome after surgical treatment. Epilepsia 1993;34:878-883.

13. Cendes F, Andermann F, Dubeau F, et al. Early childhood prolonged febrile convulsions, atrophy and sclerosis of mesial structures, and temporal lobe epilepsy: an MRI volumetric study. Neurology 1993;43:1083-1087.

14. VanLandingham KE, Heinz ER, Cavazos JE, Lewis DV. Magnetic resonance imaging evidence of hippocampal injury after prolonged focal febrile convulsions. Ann Neurol 1998;43:413-426.

15. Kobayashi E, Lopes-Cendes I, Guerreiro CAM, Sousa SC, Guerreiro MM, Cendes F. Seizure outcome and hipocampal atrophy in familial mesial temporal lobe epilepsy. Neurology 2001;56:166-172.

17. Kobayashi E, D'Agostino MD, Lopes-Cendes I, et al. Hippocampal atrophy and $\mathrm{T} 2$ weighted signal changes in familial mesial temporal lobe epilepsy. Neurology 2003;60:405-409.

18. Coan AC, Kobayashi E, Lopes-Cendes I, Li LM, Cendes F.Abnormalities of hippocampal signal intensity in patients with familial mesial temporal lobe epilepsy. Braz J Med Biol Res 2004;37:827-832.
19. Commission on Classification and Terminology of the International League against Epilepsy. Proposal for revised classification of epilepsies and epileptic syndromes. Epilepsia 1989;30:389-399

20. Secolin R, Ferreira RGM, Maurer-Morelli CV, et al. Complex segregation analysis in familial mesial temporal lobe epilepsy. Epilepsia 2004; 45:(Suppl 7):S224.

21. Scheffer IE, Berkovic SF. The genetics of human epilepsy. Trends Pharmacol Sci 2003;24,428-433.

22. Borgatti R, Zucca C, Cavallini A, et al. A novel mutation in KCNQ2 associated with BFNC, drug resistant epilepsy, and mental retardation. Neurology 2004;63:57-65.

23. Otto JF, Yang Y, Frankel WN, Wilcox KS, White HS. Mice carrying the szt1 mutation exhibit increased seizure susceptibility and altered sensitivity to compounds acting at the m-channel. Epilepsia 2004;45:10091016.

24. Catterall WA. Structure and function of voltage-gated ion channels Annu Rev Biochem 1995;64:493-531.

25. Trimmer JS, Rhodes KJ. Localization of voltage-gated ion channels in mammalian brain. Annu Rev Physiol 2004;66:477-519.

26. Misonou H, Mohapatra DP, Trimmer JS. Kv2.1: a voltage-gated k+ channel critical to dynamic control of neuronal excitability. Neurotoxicology 2005;26:743-752.

27. Wieser S, Kelemen A, Barsi P, et al. Pilomotor seizures and status in non-paraneoplastic limbic encephalitis. Epileptic Disord 2005;7: 205-211

28. Lopes-Cendes I, Scheffer IE, Berkovic SF, Rousseau M, Andermann E, Rouleau GA. A new locus for generalized epilepsy with febrile seizures plus maps to chromosome 2. Am J Hum Genet 2000;66:698-701.

29. Berkovic SF, Serratosa JM, Phillips HA, et al. Familial partial epilepsy with variable foci: clinical features and linkage to chromosome 22q12. Epilepsia 2004;45:1054-1060. 